\title{
AGRICULTURAL ECONOMICS SCHOLARSHIP IN SOUTH AFRICA AT THE CROSSROADS: IS IT TIME FOR A NATIONAL INSTITUTE OF FOOD, AGRICULTURAL AND RESOURCE ECONOMICS?
}

\author{
J.F. Kirsten*
}

ABSTRACT

This paper reflects on the standing and impact of the work of agricultural economists in South Africa to illustrate the critical decisions faced by the profession as it contemplates its future. The focus is on the agricultural economic scholarship per se and not on the policy and practice issues of the discipline. Following the review of agricultural economic research output in South Africa the paper then also raises questions about relevance and impact of the discipline and the quality of training. Given these concerns the paper makes the case for improved coordination and perhaps consolidation of the discipline and presents a proposal for the establishment of a national institute that will consolidate and improve training at the various universities as well as adequately fund and direct research. Keywords: Agricultural Economics scholarship; bibliometric analysis; South Africa

\section{$1 \quad$ INTRODUCTION}

It is indeed a great honour for me to be nominated by the Agricultural Economics Association of South Africa (AEASA) to present the F.R. Tomlinson Commemorative Lecture for 2010 . The honour is especially meaningful given that I have to present this lecture in honour of my grandfather, Professor F.R. Tomlinson. I was at the beginning of my career as an agricultural economist (having just completed my BSc Agric Hons in Agricultural Economics at the University of Stellenbosch) when Professor Tomlinson presented the first commemorative lecture on 31 October 1986, exactly 24 years ago. It is in this respect that tonight's occasion is very special to me. It is even more special given that it is probably exactly 50 years ago that the idea of an agricultural economics association of South Africa was conceived in the corridors of the Department of Agriculture by Tomlinson and his colleagues. In 2011, the AEASA will celebrate its $50^{\text {th }}$ year of existence following its establishment at the first meeting in 1961.

Tomlinson is sometimes remembered for his role in the policy of separate development and specifically for his work as Chairman of the "Commission of Inquiry into the Socio-Economic Development of the Bantu Areas within the Union of South Africa" (the Tomlinson Commission). Despite the negative connotations this contribution might hold, AEASA really honours Tomlinson's intellectual contribution related to broadening an understanding of the important role of agricultural growth and the importance of agriculture's contribution to economic development. In addition, it is also for the role he played in establishing AEASA and the agricultural economics profession in South Africa in general that the Association wanted to honour Tomlinson by introducing this commemorative lecture.

The agricultural economics discipline (hereafter the discipline) in South Africa was born 85 years ago in 1925 when Professor J.F. W. Grosskopf was tasked by the University of Stellenbosch to establish a course in agricultural economics. In 1929, Tomlinson was one of the first students to graduate with a BSc Agric (Agricultural Economics) from the University of Stellenbosch. He was also the first student in South Africa to graduate with an MSc Agric degree in agricultural economics in 1930. From these small beginnings with a narrow focus on farm management and prices, the discipline in South Africa has grown to a fairly diverse and mature discipline covering a wide variety of areas including commodity analysis, production economics, resource and environmental economics, agricultural marketing, agribusiness management, agricultural policy analysis, agricultural finance and risk management, derivative instruments, agricultural trade, etc. This lecture, therefore, provides an ideal opportunity to reflect on the profession's standing as it turns 50 and to debate the way scholarship could be strengthened and institutionally better organised.

It has become my habit to critically analyse the profession as was evident from my Presidential Address in Bloemfontein in 2002 (Kirsten, 2002) and also the paper I presented at the inaugural conference of the African Association of Agricultural Economists in 2004 (Kirsten, 2004). Both these

* Department of Agricultural Economics, Extension and Rural Development, University of Pretoria, Email: Johann.Kirstin@up.ac .za 
papers were critical of the standard agricultural economics paradigm and tried to make the case for a more institutional economics approach in the discipline. In this article, I will not repeat those issues but rather reflect on the standing and impact of the work of agricultural economists in South Africa to illustrate why they are faced with critical decisions as they head into the next decade. The focus will thus be on the agricultural economic scholarship per se and not on the policy and practice issues of the discipline. This article also documents the evolution of the discipline in South Africa and shows that the same global forces are shaping the discipline here in South Africa. I then also raise questions about relevance and impact of the discipline and the quality of training. In the final section, I also question the appropriateness of the current institutional model whereby academic departments are understaffed, and where agricultural economists responsible for academic training, analytical work, and research are scattered and thinly spread across the country. There is no critical mass, resources are wasted, efforts are duplicated, and impact is diluted. Therefore, I ask the question: "Is it thus not time for consolidation and for bringing the training, research and scholarship dimensions of the discipline together in what I propose be called the Institute for Food, Agricultural and Resource Economics (IFARE)?"

\section{THE EVOLUTION OF AGRICULTURAL ECONOMICS AS AN ACADEMIC DISCIPLINE}

This section provides a global perspective on the evolution of agricultural economics as an academic discipline. This review will be useful to put developments and evolution of the discipline in South Africa into perspective. Given that Tomlinson could be considered as one of the fathers of the discipline in South Africa it would be rather fitting to reflect on this evolution in South Africa especially given the context of this commemorative lecture.

International scholarship in agricultural economics is little more than a century old and has for most of its lifespan been dominated by American, British and to some extent German scholars. The American Economic Association (AEA) celebrates its centenary in 2010 and is considered to be the oldest professional association of the discipline with other professional associations only having been established a little later. For example, the British Agricultural Economics Society was founded in 1926, the International Association of Agricultural Economists in 1929, the Australian Association in 1957 and shortly after that, AEASA in 1961. The American Journal of Agricultural Economics (AJAE) published its centennial issue in April 2010 and Boland and Crespi (2010, pp.456-471) review the change in the discipline over the last 50 years in a paper in the autumn 2010 issue of Applied Economic Perspectives and Policy. These two resources provide a useful basis for this section of the article.

Another useful resource is the paper by Runge (2006) which provides a summary of the birth and evolution of the agricultural economics discipline. Based on his account it is evident that agricultural economics arose in the late $19^{\text {th }}$ century, combined the theory of the firm with marketing and organisation theory, and evolved throughout the $20^{\text {th }}$ century largely as an empirical branch of general economics. The birth of the discipline can be linked to the historical importance of agriculture in the United States (US) combined with the rich data compiled by the US Department of Agriculture (USDA) beginning in the mid$19^{\text {th }}$ century. The discipline was closely linked to empirical applications of mathematical statistics and made early and significant contributions to econometric methods. In the1960s and afterwards, as agricultural sectors in the Organisation for Economic Co-operation and Development (OECD) countries contracted, agricultural economists were drawn to the development problems of poor countries, to the trade and macroeconomic policy implications of agriculture in richer countries, and to a variety of issues in production, consumption, environmental and resource economics.

Agricultural economics as a discipline was largely derived from two intellectual streams as summarised by Runge:

The first was neoclassical political economy and the theory of the firm applied to farm production. The second, borne of an economic crisis in American agriculture in the late $19^{\text {th }}$ century, focused on strategies for organized marketing of agricultural commodities through collective bargaining and cooperatives. The first stream may be traced to the $18^{\text {th }}$ century enlightenment and a preoccupation with land as a factor by the French Physiocrats (2006).

These ideas of the French Phyisiocrats, such as Francois Quesnay's of the conversion of land inputs to 
agricultural outputs and profit and the emphasis on surplus production, was a critical point for many of the classical economists and provided the impetus for a strong emphasis on farm management at the Land Grant Colleges in the US. This emphasis led to the establishment in 1910 of the American Farm Management Association.

By the 1930s, when Tomlinson commenced his doctoral studies at Cornell University in the US, departments of agricultural economics were being established in many US universities, where technical and institutional issues affecting agricultural production formed the core subjects. In addition to the leading roles played by Cornell, Illinois, lowa State, Minnesota, Purdue and Wisconsin, a major research programme was established at the University of California-Berkeley with the endowment of the Giannini Foundation.

In those early years of the $20^{\text {th }}$ century, agricultural economics was only discussed in regular special sessions at the AEA meetings. In 1915, the National Association of Agricultural Economists was formed. In 1917, the AEA meeting was held jointly with the National Agricultural Economics Association and the American Farm Management Association, and talks began on a merger of the last two which was finally realised in 1919 when they merged as the American Farm Economics Association (AFFA) (Runge, 2006). In the same year, the newly established association began publishing the Journal of Farm Economics to serve those interested in the economics forces and influences as they operate to affect the business of farming (Boland and Crespi, 2010). The name of the association was retained until 1968, when it became the American Agricultural Economics Association (AAEA) and when it also changed the name of its journal to the American Journal of Agricultural Economics (AJAE) - with its focus on: "the economics of natural resources and the environment, agriculture, and rural and community development". This to some extent still reflects the broad focus of what we today consider to be the field covered by agricultural economics.

Using the evolution of the agricultural economics discipline in the US as the barometer of the global evolution of the discipline over the more or less 100 years it is evident from the article by McCalla et al. (2010) in the centennial issue of the AJAE, that the profession as it is known today was shaped by the changing economic conditions over the past century, changes in technology and developments in economic theory and quantitative methods.

From the focus in the early years on farm management and later the more technical and institutional issues related to agricultural production, by the 1960s and 1970s the profession had broadened and segregated into increasingly distinct categories or sub-disciplines that persisted until today. According to McCalla, et al. (2010), these are:

- Traditional agricultural economics of production, marketing, credit, agribusiness, research and extension and policy;

- Resource and environmental economics of land, water soil conservation, marine economics, recreation and resource degradation;

- Rural/regional economics and rural development;

- International economics of agricultural development and trade; and

- Consumer and food economics.

Runge (2006) argues that trade and development dominated agricultural economics research, especially after the mid-1980s, as global trade negotiations increasingly hinged on struggles between heavily subsidised farm sectors in OECD countries and the highly taxed sectors of the developing world. Risk and uncertainty are inherent in agriculture and their relevance has continued to draw interest from many agricultural economists especially in developing countries. Runge (2006) also mentions that the organisational structure of farms and the role of economies of scale, scope, technological change, capital and labour mobility were also receiving continuous interest from agricultural economists). Farm structure and the economics of contracting was also an additional area of risk and agency studies.

The final area of broad interest listed above, the issues of food consumption and supply chains in the food industry, obtained continued interest from agricultural economists emphasising vertical and horizontal integration and imperfect competition as forces driving the sector, with implications for consumer choice, nutrition and health.

It is evident that the agricultural economics profession has continued to reach beyond the agricultural 
sector, expanding its scope through numerous applications of relevant economic theory. Meanwhile, the high level of abstraction in economics characteristic of the last half of the $20^{\text {th }}$ century appears to have given way to new interest in empirical and experimental studies, suggesting according to Runge (2006), that the distance between agricultural economics and its mother discipline may narrow in the years ahead.

This evolution of the agricultural economics discipline as described here as well as the drop in student numbers and the changing nature of research topics have led many departments of agricultural economics in the US to change the names of their departments to include the words "applied economics" or with other emphases, such as "natural resources", "environment", and "management", added to departmental names. In response to this trend the members of the American Agricultural Economics Association voted overwhelmingly in favour in $\mathbf{2 0 0 8}$ to change the name of their association to the "Agricultural and Applied Economics Association", thus confirming the evolution and new focus of scholarly work in the discipline.

Within one century the discipline evolved from a focus on farm management and farm economics to a discipline covering a variety of topics related to agriculture, food, natural resources and the environment. In the same time the original AEA changed its name three times in response to the continuing evolution of the work of its members. Although there has not been the same trend in name changes in the departments in the United Kingdom (UK) and on the European continent those scholars have also shifted their focus to issues related to environment and food consumption and nutrition matters. Has the South Africa scholarship evolved in the same way over the first 50 years of its formal existence?

From its modest beginnings in the 1920s when the Division of Economics and Markets in the Department of Agriculture and the Departments of Agricultural Economics at the Universities of Stellenbosch and Pretoria were established, the agricultural economics discipline in South Africa has grown to make key contributions to all spheres of the agricultural and food sector. Similar to the evolutionary process in the United States, the discipline has in South Africa also evolved over the years in response to the important economic problems facing the agricultural sector and to developments in economic theory, quantitative methods, and the computational capacity to deal with these problems. The important economic problems of the agricultural sector changed over the decades in response to changes in the macro-economy, political regimes, other legislation, opportunities in world trade, technology, climatic conditions and social conditions. Elsewhere (Kirsten, 2002) I provide a detailed analysis of papers published in Agrekon as evidence of the shift in research and disciplinary focus.

The scope of agricultural economics in South Africa has thus followed the same trend as elsewhere by evolving from the initial focus on farm management, marketing board issues and aspects of agriculture in general to a discipline now also covering the economic problems of food systems, rural communities, natural resources and the role they play in economic development.

With this change in focus and given the experience of academic departments at US universities there is a tendency, especially in the US, to move departments of agricultural economics out of agricultural faculties into faculties of economics and hence become distanced from the natural sciences. Karaan (2009) argues that this appears to be based on administrative motivations and departs from the traditional strength of the agricultural economics discipline as an advanced science of applied economics and therefore considers this shift as a threat to the future of the discipline. In the same line, Prof Tomlinson pleaded in his lecture in 1986 that departments of agricultural economics should not move to other faculties. They would really like to have us, he argued, but removing our discipline from the agricultural and natural sciences will surely kill the specific advantage of the discipline of applying economic theory to problems in the agriculture, environment, food and nutrition.

The evolution of the discipline described above also brought agricultural economists in touch with other disciplines such as law, geography, sociology, ecology, mathematics, institutional theory and brought interesting dynamism to the discipline. It is, however, the excessive reliance on mathematics and mathematical modelling and econometrics that still haunts the discipline - in South Africa and globally. I raised this concern in 2002 (Kirsten, 2002) and it is comforting that our past-president, Mohammad Karaan, shares this concern. Mathematics has brought incredible rigour and enhanced our science, but as Karaan argues "it also made our work less accessible and distanced us from policy makers and business who are less concerned about our methods. Our preoccupation with the tools of our trade made us lose sight somewhat of the relevance of our trade. So while engrossed in our micro-applications, the world of business and policy faced new macro challenges that we seem less attuned to" (2009, p.2). 
The evolution of the discipline globally and the difficulty of many researchers to understand context and historical and institutional realities as well as political dynamics clearly puts questions about the relevance and impact of our discipline. The limited influence the discipline has on policy choice in South African agriculture these days clearly confirms the questions about relevance, impact, quality and contribution of our work. Our lack of understanding of the political economy and political dynamics could contribute to this state of affairs or there could perhaps be aspects related to the quality of our work that explains it. There seems to be a variety of reasons why the discipline is at the cross roads and needs to take effective stock of how it needs proceed into the future.

\section{THE IMPACT AND STANDING OF AGRICULTURAL ECONOMISTS' WORK}

In order to decide on a future course of action for the agricultural economics discipline in South Africa it is necessary for agricultural economists to do some critical self-reflection in order to gauge the health of the discipline in South Africa. This is the purpose of this section. I will restrict my remarks only to the academic departments of agricultural economics since the assessment of the life and work of agricultural economists in practice and in government will require a separate and more detailed exercise. Thus, following the title of this lecture, my focus is only on agricultural economic scholarship which is largely produced by South African academic departments.

There are eight South Africa universities that offer degree programmes with agricultural economics as a major as well as Masters and PhD programmes in Agricultural Economics. The student numbers at these universities are indicated in Table 1 below.

There are, however, other universities, such as the University of South Africa (UNISA) and the various universities of technology, that offer introductory agricultural economics modules and farm management to its students in agriculture. These universities are not included in the analysis below which only focuses on the standing of the eight departments of agricultural economics. In this regard, it is worth noting that it is a major problem for the discipline, and especially the purists in the discipline, that students graduating from the universities of technology without any advance training in agricultural economics, economics, statistics or advanced courses in agricultural sciences are labelled as agricultural economists. These "graduates" are often employed to do the work of agricultural economists. Students who went through the tough route to finish school with honours in mathematics and science and who passed a 4-year BSc Agric programme at a comprehensive university are now evaluated and remunerated in the civil service at the same level as students with a diploma or B Tech degree.

In this section, I report on the actual research output of academic departments and its standing as judged by peers and peer review systems. For this reason I have resorted to some official indicators in order to provide an objective overview of the research enterprise at different university departments. These indicators are the following:

- Publications units earned in accredited journals as submitted to the Department of Higher Education;

- Number of National Research Foundation (NRF) rated researchers per university;

- Number of (permanent) staff members with citations in journals listed on the International Statistical Institute (ISI) Web of Science.

UFS = University of the Free State; NWU = North-West University

The rating and comparison of the performance of academic departments is certainly one important indicator of the standing of the discipline as well as highlighting where relative strengths are located. The numbers in Table 2 above certainly hide other important factors such as that some of the publication units are generated by staff members that are only attached to the respective departments through Honorary or Extra-ordinary appointments or via short term (annual) contract appointments. Given that the publications are inflated by this practice it clearly does not bode well for the performance of permanent full-time academic staff. Given that most universities expect every staff 
member to publish at least one article per annum it is rather disappointing to know that if the numbers reported are adjusted, most university average numbers for the last six years will be far below 1 . This brings me to the question about the relative standing of the individual researchers.

To obtain a sense of the research output and impact of individual scholars (including those outside academia) in the discipline in South Africa, I have applied a variety of bibliometric indicators. These indicators include, amongst others, the number of papers an author has published and the number of times the author has been cited in the literature. The citation reports reflect to a large extent the quality and impact of the research output of the individual. This is expressed by the $h$-index which increases in a non-linear but more exponential manner with a higher number reflecting higher impact. There are various databases that track citations, but I have decided to use only two, namely: Harzing's Publish or Perish, a software programme that uses Google Scholar to retrieve citations from high impact journals and journals not indexed to research reports and reports on the web, and the Thomson/Reuters "Web of Science", which tracks the citations in the world's top rated journals mainly published by countries in the North.

Using these systems, I have analysed all the scholars in the discipline in South Africa using published data after 1973. In Table 3 below, I list the 25 most cited individuals in the discipline in South Africa according to Harzing. I did the same analysis for all scholars using the Web of Science and a dramatic change in impact is visible.

The data in Table 3 below are quite revealing and I am sure that most agricultural economists are unaware of these facts. The results also reflect clearly the publication behaviour of most scholars in the profession. Most of the publications are either not peer reviewed (reports, discussion documents) or published in local journals such as Development Southern Africa, Agrekon and others, which until 2008 were not included in the ISI list. With Agrekon and Development Southern Africa now included in the ISI family this is likely to change. The numbers might also change as Thomson/Reuters include the Centre for Agriculture and Biosciences International (CABI) database fully in the ISI database. The bottom line, however, is that compared to international scholars, South African research has clearly made limited international impact. Locally, it might have a high impact but the research could be viewed as rather parochial. People in practice and in the industry will argue that it is good and shows that South African research is driven by local problems and, therefore, is of a problem-solving nature. However, for academic promotions and in order to be rated as an established (or rated) scientist by the National Research Foundation (NRF), these aspects do not count for much and South African researchers tend to score low when rated by their international peers.

The researchers in South Africa who have the most international recognition based on the ISI citations and $h$-index are: Rashid Hassan, Michael Aliber, Johann Kirsten, Giel Viljoen (not listed above: 21 ISI citations and $h=3$ ), Eric Mungatana, Lieb Nieuwoudt and Nick Vink. This performance is still rather poor compared to international peers and some of the household names in the discipline. See, for example, the ISI citations and $h$-index of some of these individuals:

$\begin{array}{lr}\text { Chris Barrett (Cornell): } & 1219(h=20) \\ \text { Tom Reardon (MSU): } & 1059(h=17) \\ \text { Thom Jayne (MSU): } & 330(h=11) \\ \text { Hans Binswanger (Retired): } & 1470(h=16) \\ \text { Colin Thirtle (Imperial): } & 314(h=10)\end{array}$

To provide a different picture on the relative standing of South African scholars I have also done a similar analysis of all the leading scholars in Africa. This analysis lists eight South African researchers in the 25 most ISI cited researchers in Africa. The most cited individual is Akin Adesina, Vice-President of AGRA, with Rashid Hassan and Michael Aliber in fourth and fifth places, respectively. The picture for African based researchers is in general not pretty and is, therefore, a serious point of concern regarding the status and impact of agricultural economic scholarship on the African continent in general.

The bibliometric analysis of South African scholars in agricultural economics confirms the suspicion that there are indeed very few scholars. This is amplified by the fact that in the top 25 South African researchers listed above there are a number of names of people who have retired, or people who are no longer practising in the discipline. Another statistic worth highlighting is that in the top 25 list there are only six individuals, namely: Gerhard Backeberg, André Jooste, Gerhard Coetzee, Moraka 
Makhura, Simphiwe Ngqangweni and Dirk Esterhuizen who are not based at universities or who have not retired from universities as emeritus professors. This suggests that there is no substantive scholarship taking place outside the academic circles in South Africa. This is rather disturbing, given that good, solid agricultural economics research is required in the departments of Agricultural Economics and in the various parastatals as well as in South African agribusiness.

In total I analysed the bibliometrics of 79 agricultural economics researchers who have published in South Africa over the past three decades or more. This number included all the current permanent staff at all eight departments of Agricultural Economics. The impact of the research they produced as measured by Harzing's /z-index is presented in Table 4 below. The results indicate that 70 per cent of the researchers have an /z-index below 4 (between 0 and 3), which gives a relatively poor reflection of the quality and impact of research despite the fact that Harzing is pretty liberal in what literature is included in the analysis. When ISI analysis is applied, the number of zeros increases from 13 to 41 (or 52 per cent of researchers analysed).

Given that our research can be considered as rather parochial as most of it is published in Agrekon, the Association's journal, it is appropriate to analyse the publication trends in Agrekon. The CABI database has recorded all published articles in Agrekon, which provides an ideal basis to analyse the concentration among the authors who published in Agrekon in that specific period. Figure 1 presents interesting reading and shows that the $\mathrm{Van} \mathrm{Zyl} / \mathrm{Groenewald} \mathrm{team} \mathrm{dominated} \mathrm{much} \mathrm{of}$ Agrekon for the past 40 years. A more detailed analysis of the distribution of papers reveals that 57.5 per cent of all papers published in Agrekon in the period under investigation carried the names of only 10 authors (as sole, lead or co-author), namely: Johan van Zyl, Jan Groenewald, Lieb Nieuwoudt, Johann Kirsten, Gerald Ortmann, Mike Lyne, Nick Vink, Johan van Rooyen, Herman van Schalkwyk and Mark Darroch.

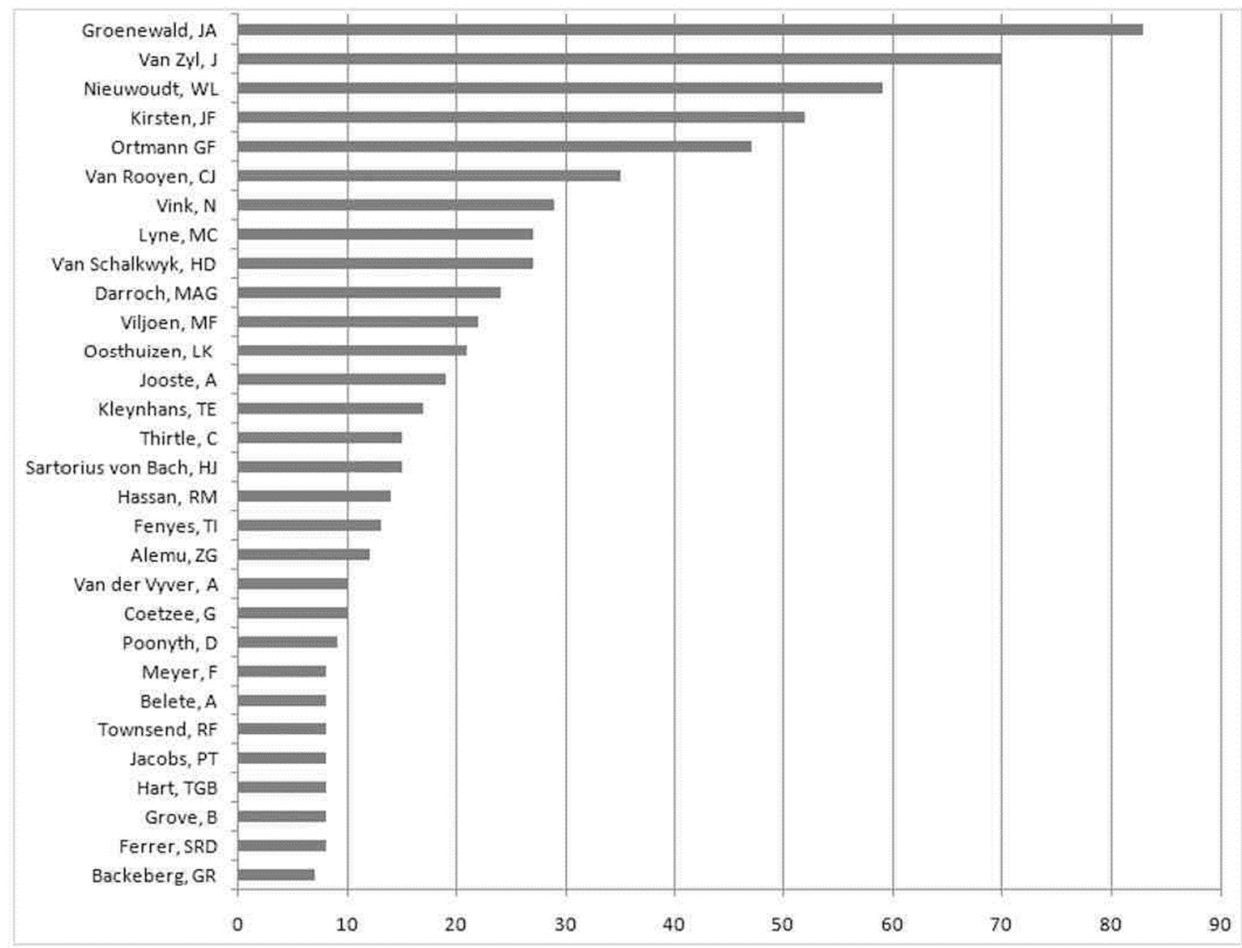

Figure 1: Top 30 authors whose names appear in articles in Agrekon: 1973-June 2010 (\# of articles published in Agrekon)

The analysis can be done in many ways, with different focuses and different points of entry, but the conclusion remains the same. There have been too few researchers in the past and there are still too few to make a substantive impact in South Africa and globally. They lack critical mass and focus and it therefore begs the question whether the discipline is organised and coordinated in an appropriate way to facilitate 
appropriate training and quality research output.

\section{THE CASE FOR A NATIONAL INSTITUTE FOR AGRICULTURAL, FOOD AND RESOURCE ECONOMICS}

\subsection{Introduction}

In the last section of this article I put forward the case for improved coordination and perhaps consolidation of the discipline. It is obviously debatable whether I should think about structure and institutions when there could be inherent problems with the discipline and the way students are trained and exposed to critical thinking. I do, however, argue that through consolidating the existing strengths and avoiding duplication it might be easier to instill the right qualities in students and young researchers who can take the discipline into the future and overcome some of the critical questions and problems raised earlier. I propose, therefore, the establishment of a national institute that will consolidate and improve training at the various universities as well as adequately fund and direct research. The case is also built on the experiences and examples from other countries which are discussed next.

\subsection{Examples from other countries}

Most agricultural economists are well aware of the USDA Economic Research Service (ERS), which employs almost 200 agricultural economists with PhD degrees. This is perhaps one of the world's best examples of a top class agricultural economics research outfit funded by government. In this section I will not describe the operation and funding of the ERS, but will rather focus on agricultural economic research institutes in other countries that operate at arm's length from government. I will list brief descriptions of a few agricultural economics institutes in selected countries to illustrate their roles. Most of them are funded by government but remain independent in their research activity and agenda.

\subsubsection{Istituto Nazionale di Economic Agraria (INEA), Italy}

The Istituto Nazionale di Economia Agraria (INEA) (National Institute of Agricultural Economics) is a public research body supervised the Ministero per le Politiche Agricole, Alimentari e Forestali (Ministry of Agricultural Policy).

The institute was established by Royal Decree in 1928 and carries out economic studies, surveys, analyses and forecasts for the agro-industrial, forestry and fishery sectors. It is also responsible for liaison between the Italian state and the European Union for creating and managing farm accounting data network (RICA) and at the same time it is responsible for coordination and alignment with the Italian National statistical system (SISTAN).

The INEA is managed by a president, a board of directors and a scientific council and has two executives and 20 regional offices. The operations of the institute are managed by a director-general and the institute has the following five departments or (services):

- Microeconomic research and analysis;

- Short-term macroeconomic studies;

- Territorial and structural research, agricultural development services;

- Environment and natural resources use in agriculture; and

- Library, publishing and telematic network.

\subsubsection{Landbouw Economisch Instituut (LEI), The Netherlands}

The Landbouw Economisch Instituut (LEI) (Agricultural Economics Institute) was established in The Netherlands in the late 1930s. In the 1970s, it became part of the Dutch Ministry of Agriculture and in the 1990 s it was privatised. The LEI currently forms part of the Wageningen University and Research Centre, within which it combines with the Department of Social Sciences to form the Social Sciences Group. The institute employs 300 people and through its research, it provides support for the decisions that governments and businesses need to make in the fields of competitiveness, the management of production chains, spatial planning, environmental protection, natural resources, the European Common 
Agricultural Policy and global trading.

\subsubsection{Australian Bureau of Agricultural and Resource Economics (ABARE), Australia}

The Australian Bureau of Agricultural and Resource Economics (ABARE) is probably known to most South African agricultural economists. ABARE first came into being as the Bureau of Agricultural Economics (BAE) as a Division of the Ministry of Post-War Reconstruction in July 1945, with the proviso that it be transferred to the Department of Commerce and Agriculture early in the post-war period. The BAE had close links with all the agricultural economics departments at the different universities in Australia. In 1987, the BAE was merged with the Bureau of Resource Economics to form ABARE to undertake economic research and analysis for agriculture and resources and energy. The majority of ABARE's activities are funded directly by the Australian government. In addition to this work, each year ABARE provides research products for clients outside the Australian government.

In July 2010, ABARE went through another merger with the Bureau of Rural Sciences to form what is now known as the Australian Bureau of Agricultural and Resource Economics - Bureau of Rural Sciences (ABARE-BRS) as a research organisation within the Australian Government Department of Agriculture, Fisheries and Forestry. ABARE-BRS will continue to provide the professionally independent economic and scientific analysis previously undertaken by ABARE and BRS. It will also provide a third capability of integrated socio-economic and biophysical analysis necessary to address the difficult policy issues facing Australia's primary industries today and into the future. The new organisation will continue to publish research for decision-makers covering the full range of policy options and will be available to undertake research funded by external parties, as has occurred in the past.

\subsubsection{Centre for Chinese Agricultural Policy (CCAP), China}

Another example of an independent agricultural economics research institute which is well supported by government finically and politically is the Centre for Chinese Agricultural Policy (CCAP). The CCAP was established in 1995 and is dedicated to high quality strategic and applied research on China's agriculture and rural economy and its natural resource base and the environment. It collaborates closely with policy makers, domestic colleagues, and international researchers working on five major policy research programmes: Agricultural Science and Technology Policy; Natural Resources and Environmental Policy; Integrated Rural and Urban Development; Poverty Alleviation Policy and Agricultural Commodity Policy Analysis and Decision Support System Programme.

The CCAP has been a member of the Chinese Academy of Sciences (CAS) since 2000, and is now one of the seven core research areas in the Institute of Geographical Sciences and Natural Resources Research of CAS. The CCAP was also one of the first institutions to be awarded the distinction of "Innovative Research Group" by China's National Natural Science Foundation.

\subsubsection{National Centre for Agricultural Economics and Policy Research (NCAP), India}

The Indian Council of Agricultural Research (ICAR) established the National Centre for Agricultural Economics and Policy Research (NCAP) in 1991 with a view to strengthening agricultural economics research through integration of economics input in planning, designing, and evaluation of agricultural research programmes and enhancing the competence in agricultural policy analysis within the National Agricultural Research System. The NCAP has 18 research scientists and undertakes and sponsors research in agricultural economics and policy analysis in the following areas:

- Agricultural technology policy;

- Sustainable agricultural systems;

- Markets and trade;

- Institutional change; and

- Agricultural growth and modelling. 


\subsubsection{Institute of Economics and Sociology at INTA, Argentina}

The Institute of Economics and Sociology is one of 16 institutes of the Instituto Nacional de Tecnología Agropecuaria (INTA) (National Institute of Agricultural Technology) in Argentina and is located in Buenos Aires city. The staff of the institute includes agronomists, economists, sociologists and statisticians. Some of the research topics the institute works on include: competitiveness and sustainability of the main value chains; production systems; constraints and incentives to adopt technology.

\subsection{Proposed format and structure}

I have argued above that the agricultural economics discipline in South Africa is at a cross roads from an intellectual and methodological point of view, but that its contribution to, and substantive impact on, policy and debate is waning given that the pool of existing young researchers and scholars is small. In addition there is unnecessary duplication of effort and focus, and at the same time quality of training and research output is not universally at an international standard. Furthermore, limited funding and poor salaries lead to insecure and non-attractive career paths for young scientists and analysts. Many young professionals find attractive careers in the private sector where their holistic views and systems thinking, embedded through agricultural economics training, help them to succeed. In the process the public sector, academia, the agricultural sector and society in general are deprived of much needed skills to work on problems of importance to society at large. I, therefore, that a national system (or institution) be implemented that will create better coordination, better quality and better impact and eventually better agricultural policies.

This idea has also been floated during debates on a new dispensation for agricultural marketing where the problem of coordination and duplication was identified as something endemic throughout South African agriculture. It is true to say that agricultural economics research and agricultural policy analysis was not spared. The National Agricultural Marketing Council (NAMC) has in recent years endeavoured to address the issue of agricultural economics research specifically related to food and commodity markets and prices by appointing dedicated researchers in a new division, the Market and Economic Research Centre (MERC) and also to make funding for research available in a coordinated fashion. It could be argued that this activity both duplicated and complemented some activities of the Directorate Economic Services and Directorate International Trade in the Department of Agriculture, Forestry and Fisheries (DAFF). It is, however, a fact that the NAMC has much more flexibility in allocating research funds and setting the research agenda since it is operating at arm's length from the Ministry and from DAFF. As a result the research output in the NAMC (via MERC) is much more concrete, visible and prominent than any of the DAFF directorates. This is largely due to the fact that they have commissioned research and published results widely.

It is true that the merits of an organisation such as the NAMC can always be debated, but the most important contribution the NAMC made over the years was the various independent enquiries and investigations it conducted, even in pre-MERC days. The reports from these activities provided several important suggestions for policy implementation that were not always taken up by the Ministry or DAFF. It could be argued that some of these investigations were not well designed, but in reality investigations are not necessarily the same as fundamental agricultural economic research. It is for this reason that the idea has been floated to upgrade the NAMC's research programme to a much more substantial national effort to create research capacity, and to perform and commission research which can ultimately better inform future decisions in the agricultural sector (assuming that the political realities and the nature of policy making will allow creative thinking).

The arguments presented earlier in the article, the poor coordination of agricultural economics research and agricultural policy analysis in South Africa, the understaffed and underfunded academic departments, and the proliferation of training programmes all point to the extreme need for the establishment of a national institute that I propose be called the Institute for Food, Agricultural and Resource Economics (IFARE).The initial building blocks of such an institute could be staffed from the following groupings:

- Markets and Economic Research programme in the NAMC;

- Directorate Economic Services, DAFF; 
- Directorate International Trade, DAFF;

- Directorate Marketing, DAFF - specifically the section dealing with policy;

- Economic Services Unit in the Agricultural Research Centre (ARC);

- Agricultural Economics Divisions in the Provincial Departments of Agriculture; and

- University departments of agricultural economics.

Whether a new act is necessary to enable this reallocation of government staff and resources or whether such a new organisation with its envisioned independence and ring-fenced funding can exist under the existing Agricultural Research Act is a matter that needs further debate and investigation. The envisioned model which I discuss below is not likely to exist under any of the current structures which will, therefore, not remove the duplication and the mediocrity which is created when too many players are involved in uncoordinated efforts on the same playing field. My vision is that this institute will be well funded by government, commodity organisations and the private sector, but it will not be controlled by any one nor the state. It will be governed by a representative Board of Governors. This Board will provide oversight and will also approve all funding and appointments. Typically, it will include representatives from organised agriculture, DAFF, ARC, deans of agricultural faculties, commodity organisations and donors. If this academic independence can be entrenched in its "memorandum of association" and confirmed politically that this is indeed what stakeholders would like to see, it will be a wonderful opportunity to include the mandate of academic training under the Institute and thereby coordinate and consolidate academic programmes in agricultural economics. Under such a scenario it could be possible for all university staff could be seconded to the Institute and receive a salary top-up to put them on a par with the salary scales of staff in parastatals and the civil service. This will help to prevent the brain drain from the universities since these staff members will not be tempted to relocate to a central office but will remain on the existing campuses (or perhaps a reduced number of campuses in a possible process of rationalisation). The proposed Institute should be led by senior academics and leading researchers and as such would be able to help universities to update their curricula, hire visiting staff, and increase their research output by retaining top students for graduate training.

\section{CONCLUSION}

I have used this commemorative lecture to reflect on agricultural economics as a discipline and in the process I have reviewed the standing of South African scholarship in the field. In so doing I have hopefully made the point that the discipline is facing critical issues as it steps into the next 50 years of existence. I have presented an "out-of-the $x$ " idea in this article which could in various ways ensure that training is improved, capacity is increased and scholarship can make a true impact on policy and decision making. Can this idea work? It all depends on whether South Africa as a country still values critical thinking and in-depth research into sensitive questions that need to be solved in the interest of society at large. It could well be that this idea is far too premature given the way policy

decisions are taken today. But, perhaps a pilot version of such an organisation can be established by universities, commodity organisations and organised agriculture and the donor community. This could be a useful challenge for someone over the next 10 years.

\section{REFERENCES}

Boland, M.A. and Crespi, J.M. 2010. From farm management to agricultural and applied economics: The expansion of a professional society as seen through a census of its dissertations from 1951 to 2005. Applied Economic Perspectives and Policy 32(3):456-471.

Harzing, A.W. YEAR. Publish or Perish, version www.harzing.com/pop.htm (accessed Day Month Year).

Karaan, M. 2009. Transformation of the Agricultural Economics profession. Agrekon 48(1): 1-8.

Kirsten, J.F. 2002. Forty years of agricultural economics scholarship and practice in South Africa: A time to challenge the consensus and refocus our intellectual work. Agrekon 41(4):251-284.

Kirsten, J.F. 2004. Expanding the frontiers of agricultural economics to meet the future challenges of agricultural development. Inaugural Symposium of the African Association of Agricultural Economists (AAAE), 6-8 December 2004, Nairobi, Kenya. 
McCalla, A., Castle, E., and Eidman, V. 2010. The AAEA: Ever growing and changing research challenges. American Journal of Agricultural Economics 92(2):334-355. April 2010.

Runge, C.F 2006. Agricultural economics: a brief intellectual history. Working paper WP06-1, Center for International Food and Agricultural Policy, University of Minnesota, http:// ageconsearch.umn.edu/bitstream/13649///wp06-01.pdf (accessed 1 November 2010).

Tomlinson, F.R. 1986. 'n Woord van dank. First F.R. Tomlinson commemorative lecture, 31 October 1986, Pretoria. 
Table 1: Students registered for agricultural economics modules and degree programmes at different universities (2009 figures)

\begin{tabular}{|l|c|c|c|c|c|c|c|c|}
\hline Year & UP & US & UKZN & UFH & UL & UV & UFS & NWU \\
\hline $\begin{array}{l}\text { Agricultural Economics } \\
2^{\text {nd }} \text { year modules }\end{array}$ & 80 & 60 & 52 & 150 & 46 & 36 & 225 & 115 \\
\hline $\begin{array}{l}\text { Agricultural Economics } \\
3^{\text {rd }} \text { year modules }\end{array}$ & 34 & 30 & 27 & 50 & 34 & 49 & 75 & 18 \\
\hline $\begin{array}{l}\text { Agricultural Economics } \\
4^{\text {th }} \text { year modules }\end{array}$ & 25 & 10 & 20 & 26 & 16 & 28 & 55 & 18 \\
\hline $\begin{array}{l}\text { Students registered for } \\
\text { Honours degrees }\end{array}$ & 13 & 7 & 1 & 24 & 15 & 0 & 33 & 10 \\
\hline $\begin{array}{l}\text { Students registered for } \\
\text { MSc Agric degrees }\end{array}$ & 44 & 5 & 9 & 8 & 8 & 8 & 20 & 3 \\
\hline $\begin{array}{l}\text { Students registered } \\
\text { for MCom or MAgric } \\
\text { degrees }\end{array}$ & 20 & 3 & 1 & 10 & 5 & 0 & 8 & 0 \\
\hline $\begin{array}{l}\text { Students registered for } \\
\text { PhD or DCom degrees }\end{array}$ & 26 & 6 & 7 & 11 & 3 & 1 & 10 & 2 \\
\hline
\end{tabular}

Key: UP = University of Pretoria; US = University of Stellenbosch; UKZN = University of KwaZulu-Natal; UFH = University of Fort Hare; UL = University of Limpopo; UV = University of Venda; UFS = University of the Free State; NWU = North-West University 
Table 2: Actual bibliometric indicators on research output of Agricultural Economics Departments

\begin{tabular}{|c|c|c|c|c|c|c|c|c|c|c|}
\hline \multirow[t]{2}{*}{ University } & \multicolumn{7}{|c|}{ Audited journal publication units } & \multirow{2}{*}{$\begin{array}{l}\text { Pub units } \\
\text { per staff } \\
\text { member } \\
\text { peryear }\end{array}$} & \multirow{2}{*}{$\begin{array}{l}\text { \# of NRF } \\
\text { rated } \\
\text { researchers }\end{array}$} & \multirow{2}{*}{$\begin{array}{l}\text { \# of staff mem- } \\
\text { bers cited in ISI } \\
\text { journals** }\end{array}$} \\
\hline & 2004 & 2005 & 2006 & 2007 & 2008 & 2009 & Total & & & \\
\hline NWU & 0 & 0 & 0 & 0 & 0 & 0 & 0 & 0 & 0 & 0 \\
\hline UFH & $?$ & $?$ & ? & 0 & 0 & $?$ & & & 0 & $1(20 \%)$ \\
\hline UFS & 4.0 & 7.0 & 11.27 & 11.39 & 3.5 & 2.42 & 39.58 & 0.82 & 1 & $6(75 \%)$ \\
\hline UKZN & 6.33 & 8.5 & 6.0 & 4.5 & 3.5 & 3.33 & 32.16 & 1.34 & 1 & $3(75 \%)$ \\
\hline UL & 0 & 0.83 & 0.5 & 0 & 0 & 2.0 & 3.33 & 0.11 & 0 & $3(60 \%)$ \\
\hline UP* & 6.33 & 13.79 & 11.3 & 14.81 & 13.6 & 14.3 & 74.13 & 1.37 & 3 & $4(44.4 \%)$ \\
\hline US & 6.33 & 4.9 & 6.33 & 3.58 & 6.2 & 9.24 & 35.59 & 0.98 & 2 & $2(33.3 \%)$ \\
\hline UV & 1.33 & 0 & 0 & 0 & 0 & 0 & 1.33 & & 0 & $1(25 \%)$ \\
\hline
\end{tabular}

Notes:

* The publication numbers for UP were adjusted to exclude the units produced by the colleagues in the Agricultural Extension discipline

${ }^{* *}$ Numbers in parentheses reflect \% of full-time staff members that were cited in ISI journals

Key:

UP = University of Pretoria; US = University of Stellenbosch; UKZN = University of KwaZulu-Natal; UFH = University of Fort Hare;

$\mathrm{UL}=$ University of Limpopo; UV = University of Venda; UFS = University of the Free State; NWU = North-West University 
Table 3: The 25 most cited researchers in agricultural and resource economics in South Africa (everything post 1973)

\begin{tabular}{|l|c|c|c|c|}
\hline Name & \multicolumn{2}{|c|}{ Harzing's Publish or Perish } & \multicolumn{2}{l|}{ Web of Science (ISI) } \\
\hline & $\begin{array}{c}\text { Citation } \\
\text { counts }\end{array}$ & h-index & $\begin{array}{c}\text { Citation } \\
\text { counts }\end{array}$ & h-index \\
\hline Johan van Zyl & 756 & 12 & 8 & 2 \\
\hline Rashid Hassan & 665 & 12 & 79 & 5 \\
\hline Johann Kirsten & 608 & 11 & 23 & 3 \\
\hline Michael Aliber & 593 & 11 & 73 & 4 \\
\hline Nick Vink & 472 & 12 & 11 & 2 \\
\hline Lieb Nieuwoudt & 311 & 10 & 14 & 2 \\
\hline Mike Lyne & 283 & 10 & 9 & 2 \\
\hline Gerald Ortmann & 255 & 8 & 5 & 1 \\
\hline Jan Groenewald & 200 & 7 & 2 & 1 \\
\hline Herman van Schalkwyk & 196 & 6 & 0 & 0 \\
\hline Johan van Rooyen & 190 & 8 & 4 & 1 \\
\hline Eric Mungatana & 138 & 3 & 41 & 2 \\
\hline Gerhard Coetzee & 130 & 5 & 0 & 0 \\
\hline Marnus Gouse & 122 & 5 & 0 & 0 \\
\hline Andre Jooste & 114 & 5 & 0 & 0 \\
\hline Moraka Makhura & 106 & 5 & 1 & 1 \\
\hline Mark Darroch & 103 & 6 & 4 & 1 \\
\hline Gerhard Backeberg & 81 & 6 & 9 & 2 \\
\hline
\end{tabular}

\begin{tabular}{|l|c|c|c|c|}
\hline Charles Machethe & 72 & 5 & 0 & 0 \\
\hline Geoff Antrobus & 71 & 5 & 10 & 2 \\
\hline Tommy Fenyes & 69 & 5 & 6 & 1 \\
\hline SA Oni & 62 & 4 & 6 & 1 \\
\hline Eckardt Kassier & 52 & 5 & 0 & 0 \\
\hline Simphiwe Ngqangweni & 51 & 5 & 0 & 0 \\
\hline Dirk Esterhuizen & 46 & 3 & 0 & 0 \\
\hline
\end{tabular}


Table 4: Impact and standing of South African agricultural economists as measured by Harzing's $h$-index

\begin{tabular}{|c|c|c|}
\hline h-index range & Number of researchers & Share of total \\
\hline $10+$ & 7 & $8.9 \%$ \\
\hline $7-9$ & 3 & $3.8 \%$ \\
\hline $4-6$ & 14 & $17.7 \%$ \\
\hline $2-3$ & 29 & $36.7 \%$ \\
\hline 1 & 13 & $16.5 \%$ \\
\hline 0 & 13 & $16.5 \%$ \\
\hline
\end{tabular}

